\title{
O DESPREPARO DA GERAÇÃO MAIS PREPARADA: QUESTÕES SOBRE A EDUCAÇÃO DOS FILHOS NA ATUALIDADE
}

\author{
Maria Christina Siqueira de Souza Campos ${ }^{1}$
}

\begin{abstract}
Resumo
O presente artigo discute os problemas que os pais têm enfrentado na educação de seus filhos, problemas esses decorrentes, muitas vezes, de seu despreparo para o desempenho de uma função, cada dia mais problemática, como resultado das transformações aceleradas da sociedade desde a segunda metade do século XX e o início do atual. Essas transformações já haviam se iniciado com a Idade Contemporânea, quando mudanças de caráter econômico e tecnológico provocaram outras de cunho político-social e cultural. Do ponto de vista social, muitas e rápidas foram as mudanças, que vêm contribuindo significativamente para a insegurança dos pais em relação à educação das crianças. Dados de uma dissertação de mestrado defendida por Zanetti em 2008 contribuíram para a ilustração e a análise das dificuldades enfrentadas na vida familiar atual.
\end{abstract}

Palavras-chave: Transformações da sociedade. Educação dos filhos. Insegurança paterna.

\section{THE UNPREPAREDNESS OF THE MOST PREPARED GENERATION: QUESTIONS ABOUT CHILDREN'S EDUCATION NOWADAYS}

\begin{abstract}
This article discusses the problems that parents have faced in the education of their children, problems that often result from their unpreparedness to perform a function, each day more problematic, as a result of the accelerated transformations of Problemas atuais society since the second half of the 20th century and the beginning of the present. These transformations had already started with the Contemporary Age, when changes of an economic and technological nature provoked others of political, social and cultural nature. From a social point of view, there have been many and rapid changes, which have significantly contributed to parents' insecurity in relation to children's education. Data from a master's thesis defended by Zanetti in 2008 contributed to the illustration and analysis of the difficulties faced in current family life.
\end{abstract}

Keywords: Society transformations. Children's education. Current problems. Paternal insecurity.

\section{Introdução}

Para se poder discutir um tema tão atual quanto polêmico como o despreparo dos pais para educar seus filhos, é preciso inicialmente discutir as causas da situação a que chegamos no início do século XXI. Para isso vamos recorrer a uma análise histórica, ainda que de uma forma abreviada, pois não é possível falar em consequências sem abordar as causas de qualquer fenômeno social. E, para não irmos muito longe, vamos retornar ao

\footnotetext{
${ }^{1}$ Socióloga, doutora em Ciências Sociais pela Universidade de Duisburg (Alemanha), livre-docente e professora associada do Departamento de Economia da Faculdade de Economia, Administração e Contabilidade de Ribeirão preto da Universidade de São Paulo, professora emérita da USP.
} 
século XVIII, quando movimentos de grande significação social introduziram grandes transformações na sociedade da época.

Em primeiro lugar, o surgimento de um movimento de caráter filosófico conhecido por Iluminismo durante o século XVIII na Europa, defendendo o uso da razão (vista como luz) contra o antigo regime (considerado como trevas), defendendo maior liberdade econômica e política. As críticas do movimento ao Antigo Regime (monárquico e autoritário) referiam-se a vários aspectos, entre os quais o sistema econômico vigente o mercantilismo -, o absolutismo monárquico, o poder da Igreja sobre a sociedade civil e, muitas vezes, contra as próprias verdades reveladas pela fé. Com base nos três pontos acima, podemos afirmar que o Iluminismo defendia: a liberdade econômica, ou seja, a não intervenção do Estado na economia, o antropocentrismo (já originado no Renascimento), ou seja, o avanço da ciência e da razão, e o predomínio da burguesia e seus ideais, que queria ocupar o lugar da nobreza. Paralelamente, na Inglaterra pregavase o liberalismo econômico, sendo Adam Smith seu principal propositor, e a Revolução Industrial estava em pleno andamento.

Como consequência da difusão do ideário iluminista, duas revoluções políticas foram detonadas, a Revolução Francesa, de 1789, e a independência americana, de 1776. Considerando somente a Revolução Francesa, embora muito do que pregavam seus propositores não tenha se consagrado, com o retorno da monarquia ao poder na França em 1815, já se podia notar certa transformação da sociedade francesa com a mudança da base do poder político, que de absoluto passou a constitucional, o alijamento da nobreza do poder político e a ascensão da burguesia que passou a ocupar seu lugar na hierarquia social. Também o liberalismo econômico se impôs como sistema econômico no lugar do mercantilismo e diversos movimentos sociais passaram a mostrar que uma nova ordem social estava em gestação. Assim, as proposições de caráter socialista, embora utópicas, já eram tentativas no sentido de instituir uma maior igualdade econômica e social. Citamse entre elas as propostas de Charles Fourier e Jean-Baptiste Godin, que, embora visassem melhorar as condições de vida dos operários franceses, perduraram somente por certo tempo.

Em 1846, o industrial Godin instalou-se em Guise (norte da França) para fundar uma empresa de utensílios de aquecimento e de cozinha, fabricados em ferro fundido, que difundiam muito melhor o calor que os antigos modelos em folha metálica, e permitiram que Godin, de origens modestas, fizesse rapidamente fortuna e se impusesse em um mercado em plena expansão. Mas ele, como simples operário que fora, havia conservado a memória das terríveis condições de vida e de trabalho dos assalariados da indústria, que pôde também constatar numa viagem que fez pela França entre 1835 e 1837. Godin decidiu, então, usar sua fortuna para melhorar a vida dos seus empregados, e propor as suas soluções para o problema da miséria dos operários. "Familistério" foi o nome dado por Godin às edificações destinadas à habitação que fez construir para os operários de sua fábrica e sua família a partir de 1859 até 1880. Inspirou-se diretamente no falanstério de Fourier, mas, como faria sempre, efetuou uma alteração na teoria para adaptá-la a suas próprias ideias e, sobretudo, para torná-la mais realizável. A primeira etapa, a mais urgente, era, segundo Godin, a de melhorar as condições de alojamento e de vida das famílias, atribuindo-lhes condições «equivalentes às riquezas». Charles Fourier, por seu lado, propôs e fundou outra instituição, o falanstério, que teve curta duração pela 
falta de recursos e pela dificuldade de implantação de uma utopia tão distante da realidade.

Assim, apesar de alguns projetos bem intencionados, a sociedade continuou a evoluir, podendo ser identificada a segunda etapa da Revolução Industrial, que atingiu países que ainda não haviam passado pela primeira etapa no fim do século XVIII, como a França e a Alemanha. A democracia americana, para se fortalecer e vingar, sofreu influência forte do Iluminismo de Voltaire e Diderot, assim como de Franklin e Jefferson e os Estados-Nação do século XIX, de Adam Smith, Montesquieu e Alexis de Tocqueville. Na Rússia, com a persistência do regime czarista até o início do século XX, duas revoluções - com base no pensamento de Marx, Engels e Lenin, acabaram por vez com o predomínio da monarquia, ambas em 1917, a ocorrida em março desse ano, denominada menchevique e a de outubro, bolchevique, que se instalou definitivamente e levou ao poder Lenin e seu grupo. Na segunda metade do século XX assistimos a novas transformações econômico-políticas e sociais. Cai o marco da transformação, o Muro de Berlim, e se desmorona a União Soviética. Diversos fatores, paralelamente, contribuíram para a transformação da sociedade: aumento da vida média da população com as descobertas da medicina, a difusão da escolarização para grande parte da população e o desenvolvimento intenso da tecnologia da comunicação.

É preciso mencionar as descobertas e invenções mais significativas do século XX que contribuíram para as transformações que têm provocado tantos problemas sociais, econômicos e políticos. Em muitos casos foram as duas grandes guerras que provocaram essas descobertas, já que os países envolvidos nesses conflitos se empenharam em descobrir meios rápidos para levar a guerra ao fim. Assim, citam-se a teoria da relatividade (Einstein), o avião (em 1903, primeiro voo documentado dos irmãos Wright e, em 1906, o primeiro voo documentado de Alberto Santos Dumont), o motor a jato (1910), a linha de produção em série em 1913 (Henry Ford), a teoria do Big Ben (1927), mais tarde sistematizada por um astrônomo americano em 1929, a técnica dos receptores de rádio durante a segunda guerra mundial, quando também tiveram grande impulso a invenção do radar, dos computadores em meados do século XX, tendo aparecido, já em 1965, os de terceira geração, os satélites (primeiro voo espacial do Sputnik, da cadela Laika, em 1957, e de Yuri Gagarin, em 1961), as fibras óticas em 1952 e, vinte anos mais tarde, seu uso em forma de cabos para a transmissão da telefonia, transmissão de dados, programas de TV e micro-ondas, em 1944, a energia nuclear. Também importantes descobertas e atuações na medicina devem ser mencionadas já no século XX, como a penicilina em 1928, fruto dos trabalhos de Alexander Fleming, o primeiro transplante cardíaco, em 1967, realizado pelo médico sul-africano Christian Barnard, a clonagem de mamíferos, em 1996, com a ovelha Dolly, e a estrutura do DNA, em 1953, entre muitas outras.

Data de 1960 a internet, que se desenvolveu durante a Guerra Fria, visando a transmissão de dados entre redes militares, e de 1992 a World Wide Web (www.). Já no século XXI apareceram poderosos meios de comunicação: You Tube, maior site de vídeos do mundo, inventado em 2005, o iPod, em 2001, tocando milhares de arquivos, o Face book, em 2003, rede social capaz de conectar pessoas de todo o mundo, um dos maiores meios de interatividade da internet. A mão biônica data de 2007, tratando-se de uma mão 
artificial com dedos que podem se movimentar de forma separada, podendo segurar diversos objetos ao mesmo tempo.

Evidentemente, são conhecidos os riscos a que nos expomos quando utilizamos qualquer um desses meios de comunicação. O Face book possibilita uma exposição pessoal em âmbito mundial, cujas consequências são imprevisíveis. A participação em grupos mais ou menos públicos por meio do WhatsApp permite que quaisquer pessoas mal intencionadas adquiram dados sobre os usuários e façam mau uso dos mesmos. Dois pesquisadores, um da Escola Politécnica Federal de Lausanne, na Suíça, e outro da Universidade Queen Mary de Londres, fizeram a leitura de meio milhão de mensagens enviadas a 178 grupos públicos e obtiveram informações detalhadas sobre 45.794 pessoas. Pode-se imaginar o que poderia ter acontecido, se essas informações tivessem caído nas mãos de indivíduos sem escrúpulos. Considerando que qualquer grupo do WhatsApp é privado, mas o administrador pode torná-lo público por meio da opção "convidar para o grupo via link", é preciso muito cuidado com o grupo de que se pretende fazer parte.

\section{A sociedade atual e suas transformações}

Muitos designam a sociedade atual em que vivemos por "sociedade pósindustrial", na qual o trabalho material é realizado por máquinas e o mental, por computadores. E onde se situa o homem nessa sociedade materialista, consumista e individualista? Se suas principais funções do passado foram assumidas pelas máquinas, esse homem se vê praticamente legado a uma posição de desfrute do prazer, que, no fundo, não lhe traz a satisfação desejada, pois ele mesmo não desempenha mais um papel primordial na condução da produção. Trata-se de uma sociedade do "politicamente correto", "do presentismo", do estar por dentro. Constata-se a proliferação das famílias monoparentais, que constituem a grande maioria nos países nórdicos, por exemplo, onde $70 \%$ das crianças nascem fora do casamento e de qualquer projeto de vida a dois. No Sul da Europa também se verifica um aumento acelerado da porcentagem de mães solteiras. Os termos-chave da sociedade atual são globalização, mundo cibernético, eficácia e rapidez. Trata-se de uma sociedade light, com primazia do fast sobre o slow, sociedade amarrada à incerteza e espectadora do ocaso dos valores. Os jovens, nessa sociedade, estão sendo levados ao planeta digital; são os assim chamados "nativos digitais". E aí se começa a questionar: $\mathrm{O}$ avanço da tecnologia explicaria os longos ciclos da história tornando-se cada vez mais curtos?

Todos os âmbitos da vida em sociedade estão sendo afetados, isto é, as assim chamadas esferas econômica, política, sociocultural, familiar e sexual, o que significa que atinge todos os aspectos da vida humana. Cultua-se também a neutralidade de gênero. Nota-se uma desorientação generalizada, uma crise sem limites, uma despreocupação com o próprio futuro, especialmente porque não sabemos o que nos espera até no dia de amanhã. Mas essa aparente despreocupação com o futuro faz que outros passem a planejar nosso futuro em função de seus próprios interesses. Um aspecto fundamental da transformação social é a concepção de tempo. Em menos de um século dobrou a expectativa de vida. Inventam-se máquinas para economia de tempo, como o telefone celular, o avião, o computador. Outras servem para enriquecimento do tempo (ouve-se rádio enquanto se guia o carro), outras ainda destinam-se a estocar o tempo, como os CDs 
e a secretária eletrônica, ou, ainda para programar o tempo (agenda eletrônica). Embora, à primeira vista, isso constitua um aspecto muito positivo, é preciso refletir bem, pois são muitas as consequências para a sociedade e a vida humana o fato de sermos mais longevos. Como seremos sustentados no futuro? A que cuidados de saúde teremos realmente acesso? Seremos relegados a viver numa casa de repouso, com certo bem estar material, mas sem apoio social e espiritual? Encontra-se depressão por toda parte, dada a complexidade da sociedade em que vivemos e a qual não conseguimos entender, muito menos dominar. Em dez anos a população da Terra será constituída por 8 bilhões de pessoas, pode-se pensar que serão 8 bilhões de cérebros em condição de pensar e resolver problemas. Se esses indivíduos dispuserem de acuidade, vivacidade, fineza de espírito, precisão do olhar, leveza rápida da intuição, rapidez mental e habilidade para driblar obstáculos, estaremos bem servidos e poderemos viver sem grandes preocupações. Será, entretanto, assim? E, neste ano de 2020, quais serão realmente os efeitos desta pandemia que está afetando a vida de praticamente toda a esfera terrestre e até quando terão que ser enfrentados por todos?

Mas, infelizmente, há uma grande diversidade entre os países do mundo e, dentro de cada um, uma diversidade ainda maior entre as diferentes classes sociais. De acordo com um relatório do PNUD (Programa das Nações Unidas para o Desenvolvimento) de 2016, que foi dado a conhecer em março de 2017, no IDH (Índice de Desenvolvimento Humano) ajustado à desigualdade - um método que relativiza o desenvolvimento humano em função da diferença entre os mais e menos abastados de um país - o Brasil é o terceiro país que mais perde posições, empatado com Coreia e Panamá e atrás somente do Irã (-40) e de Botsuana (-23). Em relação ao Coeficiente de Gini (2010-2015) - instrumento que mede o grau de concentração de renda em determinado grupo e aponta a diferença entre os rendimentos dos mais pobres e dos mais ricos - o Brasil é o quarto pior da América Latina e do Caribe, atrás somente do Haiti, da Colômbia e do Paraguai (provavelmente, se esse relatório se referisse a 2017/2018, estaríamos também atrás da Venezuela). No caso do Brasil, o PNUD afirma que, se for levado em conta o "IDH ajustado à desigualdade", o índice de desenvolvimento humano do país cairia 19 posições no ranking mundial.

Nossa sociedade na atualidade tem sido caracterizada como uma manada de elefantes sem matriarca, uma sociedade sem memória, sem referências, sem rumo, sem perspectivas claras de passado e futuro, enfim uma sociedade do aqui e do agora. Fala-se constantemente da importância da informação no mundo de hoje, mas não se pode esquecer que há uma grande diferença entre informação e conhecimento. A informação é inútil sem o conhecimento do ser humano para aplicá-la. Somente uma parte dos países pode ser considerada pós-industrial na produção e no consumo. A maioria é pós-industrial somente no consumo. A globalização abriu a vida das pessoas à cultura e à criatividade, ao fluxo de ideia e conhecimento, mas para a maioria da população humana não se deu um amadurecimento gradual que permitisse entender os fenômenos que ocorrem e fazer a seleção do que interessa ou não aproveitar e absorver. Assim, tudo é objeto de consumo: pessoas, objetos, lealdade, fidelidade, compromisso, coerência. $\mathrm{O}$ foco reside nos benefícios de qualquer ordem que se consegue alcançar. O ser humano tornou-se objeto de produção e consumo, com a busca incessante do prazer imediato, da acumulação de bens e uma alta dose de permissividade. 
Segundo Bauman (2011), trata-se do homem que escolhe, tudo é engano, excesso e desperdício. Denigrem-se os produtos atuais e se oferecem outros, que levam à criação de novas pautas de comportamento, que se alojam no DNA da sociedade atual. O êxito depende do marketing e não da qualidade. É a sociedade do fast food, do fast sex, do fast fashion. Quanto aos valores, percebe-se nitidamente a perda de referências claras, pois os valores do mundo atual são de natureza material (não mais atemporais), busca-se a satisfação instantânea e se buscam os psiquiatras e psicólogos para se tentar pôr ordem no próprio interior. No âmbito das relações interpessoais, há uma disposição constante para mudança de táticas e abandono de compromissos e lealdades. No trabalho os antigos companheiros tornam-se competidores, rompem-se pactos e alianças e, o que é mais preocupante, as relações pessoais sempre ou quase sempre ocorrem online. Cria-se um mundo próprio, longínquo e impessoal. Cresce o número de amigos no face book, sem contato pessoal e sem se falar. Trata-se de um isolamento puro, relações precisas e sem compromisso, uma total desvinculação. No âmbito da comunicação, nota-se um desejo voraz de informação imediata, aqui e agora. A cada momento chegam informações de todos os lugares do mundo.

Mas o que se observa é um afastamento de bases de apoio e orientação, o desmantelamento dos partidos (não só no Brasil), a dominação de líderes sem carisma e sem propostas sérias, uma progressiva convergência dos programas eleitorais, um enfraquecimento do conceito de pátria, da identidade e das fronteiras. A maioria dos países do mundo tem governantes que demonstram não saber como resolver os problemas que os afetam. Os governantes não conseguem considerar a felicidade dos cidadãos como principal objetivo de todo bom governo. No tempo da dominação do comunismo em parte considerável do planeta, sabiam como distribuir a riqueza, mas não sabiam como produzi-la suficientemente e nos países capitalistas, sabiam produzir a riqueza, mas não sabiam distribuí-la. As oito pessoas mais ricas do mundo detêm uma fortuna equivalente à da metade da humanidade. Antes, sentia-se orgulho e segurança, mas hoje não se sabe para que lugar é mais conveniente ir. E, segundo o filósofo e escritor do Império Romano Sêneca (4 A.C. Córdoba - 65 D.C. Roma), "nenhum vento é favorável ao marinheiro que não sabe para onde ir". Passados tantos séculos, será que sabemos para onde queremos ir? E, se soubermos para onde queremos ir, será que teremos condição de ir até lá com todos os obstáculos que se interpõem a nossos desejos?

Se isso é positivo, de certo ponto de vista, por outro lado, esse acúmulo de informações tende a nos narcotizar, pois como diziam já há bastante tempo dois sociólogos americanos Lazarsfeld e Merton (1978), isso produz um efeito indesejável: ao nos sentirmos informados, tendemos a achar que nosso papel já está desempenhado, não sendo mais necessário reagir, tomando providências para corrigir algo errado, colaborar para resolver um problema. $\mathrm{O}$ alcance da tecnologia da informação atingia até certo tempo atrás 7 bilhões de linhas telefônicas celulares, 2,3 bilhões de pessoas com smartphones, 3,2 bilhões de pessoas com acesso à internet. Por outro lado, em 2015, havia, segundo o PNUD, mais de 200 milhões - dos quais 74 milhões de jovens de desempregados e 21 milhões de pessoas submetidas a trabalhos forçados. Enquanto $81 \%$ dos domicílios dos países ricos dispõem de acesso à internet, somente em $34 \%$ dos países em desenvolvimento e em $7 \%$ dos lares dos países menos desenvolvidos isso acontece. 


\section{A infância e a adolescência no mundo atual}

Vamos analisar com mais vagar o que está se passando com a infância e a adolescência no mundo de hoje. A importância atribuída a essas duas etapas da vida do homem é um fenômeno que data já da Idade Moderna, segundo Philippe Ariès (1975), um historiador francês conhecido que se dedicou ao estudo do trajeto de consolidação do sentimento de infância. A atribuição de importância à infância constituiu um longo processo que somente no século XVIII poderia ser considerado já consolidado. Mas, mesmo assim, a situação era bastante distinta de acordo com a classe social analisada. Entre os que sabiam ler e escrever descortinava-se um "mundo de novos fatos e percepções" (POSTMAN, 1996, p. 42), enquanto entre os iletrados os interesses se assemelhavam aos que predominavam na Idade Média. Segundo Postman (1999), como os saberes dos adultos e das crianças eram distintos, já que a formação educacional dos primeiros constituía um marco que separava as duas etapas da vida, a idade adulta tinha que ser conquistada pelas crianças, o que significava "uma realização simbólica e não biológica" (p. 50). Segundo Ariès (1975), já no século XV os homens adeptos da ordem, esclarecidos, procuraram difundir a ideia de que as crianças precisavam ser educadas com disciplina e segundo princípios estritos. Com base nessa ideia desenvolveu-se um sistema disciplinar muito rígido, muitas vezes humilhante, nos colégios internos, que constituíam a forma de educação predominante nas camadas sociais de mais posse na sociedade. Essa rigidez na educação visava desenvolver nas crianças o autocontrole necessário para modificar os comportamentos mais espontâneos tornando possível a aprendizagem.

Com a reação da opinião pública a esse regime disciplinar tão rígido - que via na criança uma fraqueza natural que precisava ser corrigida -, ele foi suprimido e se passou a uma posição contrária, ou seja, passou-se a considerar a necessidade de despertar na infância a responsabilidade do adulto, sua dignidade. Ariès (1975) acentua que essa preparação exigia cuidados e etapas, o que foi posto em prática durante o século XIX. O conceito de criança passou a caracterizado pela frequência escolar e por estágios que deveriam ser alcançados a cada faixa etária. Outra modificação importante dessa época foram o novo modelo de família moderna e a reformulação no relacionamento entre pais e filhos. Postman (1982) enfatiza que os pais passaram a ser tutores, guardiões, protetores, mantenedores, punidores, árbitros do gosto e da retidão. Assim, os pais passaram a ser educadores e teólogos, pois entre suas funções deveriam tornar seus adultos instruídos e tementes a Deus. Só com a ampliação do número de escolas, essas responsabilidades passaram a ser delegadas para as instituições de educação e as famílias se concentraram em torno das crianças, com maior intimidade doméstica. E, com isso, a saúde e a educação mais ampla passaram a ser as duas principais preocupações dos pais no século XIX.

No entanto, no século XX, desponta a família moderna, muito mais preocupada com a preparação dos filhos para o mundo do trabalho e, portanto, com a educação formal, para preparálos para a carreira e o futuro. De acordo com Ariès (1975), a família passou a pôr toda a sua energia na promoção das crianças, a sociedade colocando a responsabilidade nos pais e mestres - assim como também no governo - pelo que cada criança será no futuro.

Segundo Postman (1982), a infância atualmente está desaparecendo enquanto representação histórica e socialmente construída. A informação passou a ser divulgada de maneira incontrolável, vista como uma mercadoria de valor mundial, extremamente acessível a todos num curtíssimo espaço de tempo. Isso tendeu a destruir a linha divisória entre a infância e a idade adulta, pois agora não há mais exigências complexas nem à mente nem ao comportamento para que se 
compreenda o que está sendo veiculado e porque não quer distinguir seu público. Não há mais segredos no ambiente da televisão e, muito menos, no dos meios de comunicação mais recentes, como a internet, o que faz resultar na inexistência da infância. Sabendo tudo o que qualquer pessoa sabe, as crianças se tornam seres em condições de igualdade com os adultos, passando a reivindicar um lugar de igualdade na sociedade e na família, em particular. Consideram a inexistência de razão para serem tratadas com autoridade.

Segundo Sandra Zanetti (2008), no passado, acreditava-se na necessidade de se colocar diante da criança com autoridade para que se tornasse disciplinada e, muitas vezes, se confundia essa atitude com uma postura autoritária. Hoje, com o passar do tempo, o autoritarismo passou a ser criticado e bastante combatido. Hoje, ao contrário, chegou-se a uma atitude oposta, pois são tantos os "ditos" especialistas que têm algo a dizer sobre a forma como as crianças devem ser educadas, como se deve falar e agir com elas, que os pais começam a desconfiar de sua capacidade como educadores. O resultado foi a disseminação da ideia de que o saber natural paterno não é qualificado em comparação com o conhecimento dos assim chamados especialistas e, se os pais não dispõem de competência para educar, não podem se responsabilizar completamente pelo preparo de seus filhos para a vida adulta na sociedade. De acordo com Lebrun (2004), o discurso da ciência, por subverter o equilíbrio interior da família, acabou de vez com a autoridade paterna. Há, em decorrência da importância adquirida pelas conclusões da ciência em nossa sociedade, a promoção de uma organização social sem referência, o que leva à dificuldade crescente de os pais dizerem "não!". E diante dessa dificuldade não há possibilidade alguma de a sociedade vir em auxílio destes, pois foi dela que partiu a contaminação que atingiu a família.

Diante da deslegitimação da autoridade, a ciência vem a ocupar o lugar da função paterna. Assim, os pais não se sentem aptos a emitir julgamentos, a tomar decisões com base em seus conhecimentos e saberes, a acreditar na importância e na necessidade de manterem o princípio da autoridade em seu relacionamento com seus filhos. Chegam mesmo a perder a noção sobre o que devem fazer no que se refere a até questões simples da vida cotidiana. E, de acordo com Zanetti, "como as regras da educação não estão claras para os pais, tornam-se inconsistentes diante dos filhos." (2008, p. 50). Essa indecisão, inconsistência dos pais, os faz mais permeáveis às novas ideias e teorias modernas de educação. Tornam-se dominados pelo sentimento de culpa, que os paralisa diante de situações que exigem a colocação de limites pelos pais.

Muitos pais têm medo de desempenhar seu papel de educadores, confundindo autoridade com autoritarismo. Dizem: "TENHO MEDO DE SUFOCAR SUA PERSONALIDADE OU SUA CRIATIVIDADE". Autoridade e autoritarismo são coisas muito diferentes. Ambas as palavras têm o mesmo radical: autor. Mas, enquanto a primeira pode ser entendida como o poder de impor limites necessários para a convivência em sociedade, a segunda indica um exacerbamento desse poder, realizado pela simples imposição de uma ideia sem possibilidade de contraposição.

É exatamente por confundir e misturar os significados de autoridade e de autoritarismo que tantos pais, hoje, têm medo de exercer qualquer forma de poder sobre seus filhos - seja ele justo e necessário à boa educação da criança ou um poder ilícito e prepotente, ditado apenas pelo desejo arrogante de se impor a qualquer custo. Em qualquer tipo de relação humana, o autoritarismo é sempre estúpido e nefasto. Mas, em relações do tipo professor/aluno e, sobretudo, nas relações entre pais e filhos, a autoridade é indispensável para a construção sadia da criança. 
A autoridade enfrenta séria crise na sociedade contemporânea. Levadas ao exagero, sentenças do tipo "é proibido proibir", que se transformaram em palavras de ordem nos anos hippies das décadas de 1960 e 1970, fizeram muito mais estragos do que se poderia supor naqueles momentos de farra libertária. Plantaram nas mentes e nos corações a convicção falsa e perigosa de que, na vida, tudo são direitos e nada é dever.

Não se pode esquecer, mesmo hoje, que as relações domésticas entre pais e filhos devem continuar a ser baseadas em autoridade e poder por parte dos pais, pois na família há posições hierárquicas, direitos e deveres específicos e desiguais. A relutância ou dificuldade dos pais em usarem de sua autoridade, quando necessário, faz que os filhos acreditem ser "sujeitos de direitos", seja no interior ou no exterior do ambiente doméstico, ficando de lado a condição de "sujeitos de deveres". São os próprios pais que contribuem para o prevalecimento no seio da família do individualismo dos filhos no lugar de atitudes voltadas para o bem coletivo. Há uma evidente perda de referenciais pelo fato de que os pais não querem repetir erros ocorridos na sua própria educação; ao contrário querem proporcionar a seus filhos o máximo de bem estar de que são capazes e, assim, acabam por criar normas idealizadas de como devem educar. Tudo isso leva ao sentimento paterno de incompetência e falta de referência.

Acresce-se a isso o fato de que na sociedade atual não só a família e a escola atuam no processo de formação e educação das novas gerações. A socialização destas, muitas vezes, é mais produto da cultura de massas do que da ação das instituições educadoras propriamente ditas, transmitindo valores e padrões de conduta. De acordo com Said (1998), o poder da mídia é tal na atualidade que é ela que passa a definir os parâmetros de sociabilidade, de estilos de vida, de experiências e da construção de subjetividades.

No ambiente social, há uma forte culpabilização individual pelo fracasso, de qualquer tipo que seja; paralelamente, a cultura está marcada por uma acentuada fragilização dos laços sociais, o que é um reflexo das condições precárias de existência num mundo globalizado de dominado pela competição. Os pais, querendo dar aos filhos tudo o que não puderam ter e não o conseguindo fazer, sentem-se culpados. Esse sentimento de culpa é tanto mais profundo quando têm que deixar os filhos em creches, escolinhas ou até diante da televisão ou com babás para poderem trabalhar. Esse sentimento de culpa, segundo Zanetti (2008), funciona como um paralisante diante do medo de ressentimento dos filhos ou quando não conseguem se colocar com autoridade diante dos filhos por se sentirem em dívida com eles.

Do ponto de vista psicológico, no processo de formação ou construção da individualidade, os indivíduos assumem modelos criados pela mídia, levando à internalização de ideias, valores, hábitos mantenedores do status quo de uma sociedade tão irracional quanto autoritária. Nossa cultura acaba valorizando novas formas de relacionamento, baseadas na perda de confiança dos grupos, na fragilização dos laços, de acordo com Zanetti (2008), fazendo que se chegue a denominá-la como "sociedade morta", no sentido de estar "não-viva", pouco preocupada com as necessidades dos indivíduos e muito mais com as necessidades econômicas. Assim, pode-se dizer que fatores socioeconômicos têm interferido na formação das subjetividades e nas formas de relacionamento na atualidade, que são sustentadas e manipuladas pelos meios de comunicação de massa. Esses fatores atuam no universo familiar, nele introduzindo valores de igualitarismo, individualismo e liberdade, cuja base é a falta de confiança e compromisso dos indivíduos na sociedade. Segundo a autora acima, os fatores históricos, culturais e sociais influenciam o âmbito psicológico dos indivíduos, de modo que as subjetividades ficam marcadas por estratégias 
narcísicas de sobrevivência presentes na família, com a formação de uma estrutura na qual a autoridade dos pais perde o sentido.

Nos consultórios, os psicólogos especializados em problemas de família ouvem esses mesmos desabafos todos os dias. Qual é a causa dessa grande desordem familiar? A ausência da autoridade, dizem os especialistas. Esses pais, que pensam cuidar bem de seus filhos e procuram ser os mais zelosos e atentos possível, não impõem aquilo que deveriam impor. Seja porque rejeitam, "por princípio", toda posição de autoridade, seja porque, embora querendo manifestar sua autoridade, não conseguem mantê-la por mais de alguns instantes.

Sabemos todos, no entanto (e os educadores que trabalham em comunidades periféricas carentes melhor do que ninguém), que é a falta de educação e, portanto, de autoridade - familiar, escolar ou social - que fabrica a delinquência. Educar uma criança significa ensiná-la não só conhecimentos sobre diversas áreas mas também prepará-la para a vida de adulto. Em nossa vida adulta, confrontamo-nos, a todo o instante, com frustrações e obstáculos que, muitas vezes, nos impedem de alcançar aquilo que almejamos. Assim, é necessário que desde cedo aprendamos, não a espernear porque não conseguimos o que desejamos, mas refletir se o que desejamos é passível de ser alcançado e como podemos fazê-lo, descobrindo que certos objetivos não estão a nosso alcance ou nem são realmente importantes, não valendo, pois, nossos esforços para conquista-los.

A crise da autoridade parental é real e se reflete em projeções danosas em todos os demais aspectos da sociedade. Quem, ao visitar algum casal amigo com criança pequena nunca ouviu, às 10 horas da noite, desculpas do tipo: "Ele não quer ir dormir", "é um inferno toda vez que chega a hora de fazer os deveres da escola", "ele faz tudo o que lhe dá na cabeça"...

Para que os pais consigam superar o problema da falta de autoridade, é preciso, em primeiro lugar, que eles superem suas próprias resistências internas, às vezes muito sólidas, que se opõem ao exercício da autoridade. Para a moderna psicologia, são os medos dos pais que os impedem de se posicionar de modo correto. Claude Halmos, importante psicanalista francesa, explica quais são esses medos e como se livrar deles em seu livro L'Autorité expliquée aux parents (A autoridade explicada aos pais), lançado há pouco na França pela Editora Nil.

“TENHO MEDO QUE MEU FILHO DEIXE DE ME AMAR.” Para Claude, esse é o medo que vem em primeiro lugar. $\mathrm{O}$ medo de ser rejeitado leva o genitor a dizer sempre "sim" e a proibir o menos possível. Esse medo, no entanto, parte de uma ideia falsa, segundo a qual uma criança seria feliz "sem limites". Ora, ao contrário, é quando uma criança é deixada entregue a seus próprios impulsos e desejos que não poderá ser feliz. Ela estará limitada, incapacitada para a vida social e a escola, pois não saberá respeitar as regras que possibilitam a convivência. Estará, mais tarde, também despreparada para a vida a dois, pois esperará que seu companheiro ou sua companheira lhe permita lhe permitam tudo, como faziam seus pais.

A autoridade é uma prova de amor e não de desamor. Podemos dizer a nosso filho: "Se eu não amasse você, não me importaria com aquilo que você vai se tornar e o deixaria fazer tudo o que lhe desse na telha."

Mas, atenção! Certas formas de autoridade - que deveríamos chamar, mais apropriadamente, de autoritarismo - podem efetivamente "quebrar" a personalidade de 
uma criança. A “autoridade de domador", por exemplo, que pretende submeter a criança ao poder arbitrário do adulto: “Eu sou seu patrão, você tem de me obedecer!” Mas a autoridade verdadeira a que se refere Claude em seu livro é diferente por duas razões.

"A primeira é que ela se dirige a uma criança que ouvimos e respeitamos. A segunda é que não exigimos uma submissão da criança ao adulto, mas uma submissão à regra enunciada por este último, à qual todos também estamos submetidos (não bater nos outros, não roubar etc.)." Essa autoridade verdadeira, além de não arranhar a personalidade da criança, favorece o seu florescimento. Quando evolui num universo devidamente sinalizado no qual a interdição é claramente colocada e compreendida, a criança se sente em segurança e encorajada para a criatividade.

“TENHO MEDO DE SER UM PAI VIOLENTO.” Bastaria uma única palavra, um único tapa para traumatizar uma criança para todo o sempre; é necessário, assim, engolir o sapo e permanecer impassível diante de uma criança em crise de birra desenfreada. "Essas falsas convicções, devidas em grande parte a uma leitura equivocada da psicologia da criança, constituem a raiz desse medo", explica Claude. Esse medo, no entanto, é perigoso, uma vez que, ao proporcionar aos pais uma imagem muito negativa da sua agressividade, inibe-a totalmente. Ora, segundo Claude, quando somos levados ao desespero por uma criança que grita, dá chutes e quebra as coisas, é legítimo e desejável exprimir a própria cólera, mesmo se os meios pelos quais nós a expressamos não sejam sempre aqueles que teríamos gostado de usar. Assim, a criança compreenderá que seus pais - e os outros, de modo geral - são, como ela, sensíveis às agressões. O respeito pelos outros começa pelo respeito aos próprios pais. Mas o respeito nunca transita em mão única. Para ensinar a uma criança o que é o respeito ao próximo, é preciso primeiramente mostrar que você a respeita.

"TENHO MEDO DE PUNIR." Fica subentendido: "Prefiro conversar." Como se a punição fosse um insulto à inteligência da criança... Para Claude, a punição, quando não é humilhante e é proporcional à falta cometida, não constitui uma forma de maustratos. "A punição é indispensável. A proibição deve ser ensinada à criança. Se ela transgride uma primeira vez, um chamado à ordem pode bastar. Mas se ela continua a transgredir, a punição é indispensável e cada genitor deve dar a punição que lhe parecer mais adaptada à criança, à sua idade e à gravidade da transgressão. Como uma criança poderá compreender a importância de uma regra se a punição não se segue de forma adequada à sua transgressão?"

Na opinião da psicóloga, é bem mais prejudicial para a criança e a sociedade que ela cresça com a ideia falsa e perigosa de que pode fazer o que bem entende, inclusive cometer atos maldosos, e gozar de toda impunidade. Sem contar que o genitor que se limita a falar, em vez de repreender, acaba por perder toda credibilidade aos olhos do seu filho. A punição serve também para fazer com que as palavras dos genitores sejam respeitadas, dando a elas peso e sentido e evitando que sejam transformadas num blablablá inofensivo.

"TENHO MEDO DE CONFLITOS." A vida da família deve se desenrolar num clima de bom humor e serenidade... Essa fantasia utópica é sedutora e amplamente compartilhada, porém impraticável. O conflito é inevitável pelo simples fato de que a criança sempre se opõe aos limites, pelo menos nos primeiros tempos, e que o enfrentamento contribui para o fortalecimento da sua estrutura, embora muitas vezes 
consuma uma enorme quantidade da energia dos pais. Uma criança pequena não é ainda um ser civilizado: ela é dominada pelas suas pulsões, pelo "princípio do prazer" e pelo sentimento de onipotência; para que ela se torne um ser civilizado, deve transformar o seu funcionamento inicial. Para que isso aconteça, a autoridade de seus pais é indispensável. Uma criança se constrói ao se opor. Essas divergências criam inevitavelmente fricções. Para Claude, assumir essas fricções, sem procurar a qualquer preço preservar a paz do momento, significa simplesmente cumprir com o seu dever de educador.

Eu gostaria aqui de acrescentar o seguinte, analisando um pouco nosso país. Prestando atenção ao que está acontecendo atualmente em nosso país, em todas as esferas do poder governamental, seja ele executivo, legislativo ou judiciário, todos percebem que estamos vivenciando uma total confusão entre autoridade e autoritarismo, de tal modo que se geram situações de descalabro caótico, de verdadeiros sambas do crioulo doido nos quais o grampo e a espionagem campeiam soltos e ninguém leva a legalidade e a democracia realmente a sério. O problema não é de hoje, mas vem crescendo há bastante tempo. Quem não aprendeu desde cedo a ter consciência de limites tenderá a viver e a manifestar até o fim sua patologia de descomedimentos.

\section{A atuação dos pais como proposta no momento atual}

Por tudo o que se viu acima, percebe-se que os pais precisam aprender a se tornar pais, precisam passar por um processo de parentalização, pois não basta ser pai ou como tal ser designado. Houzel (2004) distingue três eixos ou aspectos envolvidos na parentalidade: o exercício da parentalidade (questões de ordem jurídica em relação ao exercício da parentalidade), a experiência da parentalidade (aspectos conscientes e inconscientes do fato de ser pai e/ou vir a sêlo, isto é, o preenchimento do papel de pai) e a prática da parentalidade (funções cotidianas e os níveis de interação entre pais e filhos). Portanto, os pais primeiro imaginam em que consiste o papel de pai ou mãe e depois, quando o filho nasce, há uma espécie de confronto entre o bebê imaginário e o real, precisando os pais se adaptar às necessidades do recém-nascido. A parentalidade vai se formando e se consolidando em ação, sendo produto da intersubjetividade e da transmissão intergeracional. É preciso que a criança em formação perceba que pais e filhos têm atribuições diferentes e não são iguais. Isso vai assegurar que o saber dos pais será reconhecido como o poder que coloca as interdições e fixa as regras, de maneira cultural, que constituem o núcleo da parentalidade e os alicerces da organização social.

Uma condição fundamental para que o exercício da parentalidade se desenvolva de forma coerente e bem estruturada e que a criança possa ter um desenvolvimento emocional satisfatório é que o relacionamento entre os pais seja anterior ao nascimento do filho, isto é, que tenha havido um tempo de convivência entre os pais que lhes tenha permitido construir laços estáveis, que lhes tenha dado condições de crescimento, aprendizado, bem-estar e trocas, uma forma de cumplicidade, respeito mútuo, afetividade e comunicação, de modo que tenham confiança um no outro, que conheçam a forma de pensar e agir do companheiro, o que favorecerá a formação de uma base sólida para o exercício futuro da parentalidade. Uma relação conjugal forte constituirá, sem dúvida, um fundamento ideal para o desenvolvimento emocional dos filhos.

Não se pode esquecer que a família é a instituição social, ao mesmo tempo em que é uma estrutura, responsável pela transmissão e inserção da criança na cultura e no universo simbólico e isso é realizado por meio das funções parentais. Portanto, mesmo que queiram, os pais não podem 
abrir mão dessa responsabilidade. Se existe a categoria de pais, é porque existe a categoria de filho. O que está acontecendo hoje é a diluição da diferença necessária a esse ordenamento, uma espécie de renúncia do adulto em educar uma criança. A cultura do narcisismo leva os pais a só enxergarem as "perfeições" do filho e a esquecerem ou ignorarem todas as suas deficiências. São capazes de esquecer todos os privilégios que reivindicavam para si e a satisfazer todos os desejos do filho, para que ele possa ter o que os pais não puderam. Suas necessidades serão satisfeitas a qualquer custo, seus sonhos terão que ser realizados: "o menino se tornará um grande homem e um herói em lugar do pai, e a menina se casará com um príncipe como compensação para sua mãe." (FREUD, 1914b/1969, p. 97s.). A criança ocupa na sociedade moderna, que cultua o individualismo e o narcisismo, o lugar do ser ideal, porque é, na família, o ser capaz de realizar todas as frustrações que seus pais carregam. $\mathrm{O}$ adulto passa a sustentar sua existência individual na imagem ideal da criança, que será o adulto que ele não foi, a quem, de fato, nada poderá faltar.. De acordo com Arendt (2001), no mundo atual a autoridade foi recusada pelos adultos e isso pode significar somente uma coisa: os pais se recusam a assumir a responsabilidade pelo mundo ao qual trouxeram as crianças, é como se dissessem ao filho: "recuso-me a ocupar o lugar de seu pai ou de sua mãe na estrutura de parentesco". E dessa negação decorre a impossibilidade para a criança de ocupar na estrutura o lugar de filho.

Na primeira infância, quando a criança está por volta de dois anos de idade, gasta uma boa parte de seu tempo fazendo tentativas seguidas de independência. Geralmente, é incontrolável e impulsiva, querendo ter seus desejos atendidos imediatamente. É o início do período de afirmação da identidade recém-descoberta. Mas, aos três anos, já começa a se libertar de sua completa independência anterior de mãe e de pai. Em consequência, não quer receber ajuda. Está apta a conviver com a família e está começando a se afirmar. Entre três e quatro anos, será mais difícil de controlar, mais tenaz quando deseja algo e, como já emprega uma linguagem mais desenvolvida, consegue se expressar utilizando um vocabulário mais rico para reforçar suas exigências. Tudo o que se opõe a ela é ruim, mau e objeto de agressão, mas como ela não pode agredir os pais por medo da punição ou da perda de sua amizade, ela tende a ceder. Isso porque ela tem necessidade do adulto. De quatro a seis anos, ela já tem certa noção de tempo e capacidade de lidar com sua insatisfação. Aprende o significado do "daqui a pouco", do "amanhã", que acontece depois do cair da noite. Posteriormente aprenderá a noção de passado. Ela quer também aprender o que é real em seu mundo e saber distingui-lo do mundo do faz-de-conta de sua imaginação. Certamente ela quer ver até onde a deixam ir, podendo se tornar muito mandona e dominadora. Se tiver a felicidade de encontrar um adulto paciente que possa explicar o que é aceitável e o que não é, ela se sentirá melhor e poderá adequar seu comportamento ao que dela esperam seus pais. É muito importante que os pais consigam combinar entre si os regulamentos sobre o comportamento da criança e que se mostrem coerentes para que a criança não se utilize dessas situações para jogar um pai contra o outro.

Quando atinge cinco anos, a criança geralmente está ampliando sua capacidade de conhecer o mundo externo. Consegue tolerar suas frustrações e precisa enxergar a disciplina e as exigências dos pais como justas, o que a leva a apresentar certa cooperação voluntária. De acordo com Freud, o menino nessa fase tende a apresentar certo ciúme do pai e o vê como rival. Embora costume se queixar do pai à mãe - questão em que a mãe não deve entrar -, o menino admira a firmeza e a superioridade de seu "rival-modelo". Também a menina apresenta traços do Complexo de Édipo, ainda segundo Freud, traços esses que, entretanto, se dissiparão quando ela perceber que seus desejos nunca se realizarão. 
A criança tende a apresentar comportamentos agressivos tanto em casa como na escola. Isso, até certo limite, é normal e constitui, segundo Winnicott (1999), uma base do brincar e do trabalho, mas o adulto tem que "impedir que essa agressão fuja do controle, proporcionando uma autoridade confiante" (1999, p. 101). Ainda de acordo com esse psicanalista, é tarefa dos pais e professores cuidar para que as crianças nunca se vejam diante de uma autoridade tão fraca a ponto de ficarem livres de qualquer controle ou, por medo, assumirem elas próprias a autoridade. Zanetti (2008, p. 87-90) ainda acrescenta que todas as crianças tendem a ter esse comportamento agressivo naturalmente no modo de se comportar e necessitam de pais confiantes, fortes e amorosos de tal modo que possibilitem a expressão e a contenção desses comportamentos para que elas não necessitem, por si sós, reprimi-los, tornando-se adultas tímidas ou deprimidas ou, ainda, tirânicas quando sentem que seus pais não são fortes o suficiente para contê-las ou que passem a ter um sentimento de culpa que impeça sua capacidade de ser espontânea e brincar livremente. A conclusão dessa autora é que comportamentos de agressividade, teimosia e manha em crianças pequenas estão relacionados ao fenômeno de 'fragilização dos papéis parentais' à medida que, quando em excesso, podem refletir a dificuldade que essas crianças estão tendo para lidar com seus impulsos, à medida que sentem que não podem contar com pais 'confiantes e fortes' que as ajudem nessa tarefa. Assim, a presença do 'princípio de autoridade' na família ultrapassa um caráter de valor cultural, podendo implicar consequências sérias para o desenvolvimento psíquico das crianças. O sentimento de liberdade excessiva pode gerar na criança, ao contrário do que se possa pensar, comportamentos relacionados não a tudo o que lhe dá prazer, mas, sim, àqueles que expressam sua angústia e que procura, num outro quadro de referências, num outro ambiente (como o das professoras), alguém que a ajude a contê-la e possa se tornar a fonte de amor e confiança. De acordo com o psicanalista Winnicott (1999), a criança antissocial está simplesmente "olhando um pouco mais longe, recorrendo à sociedade em vez de recorrer à família ou à escola para the fornecer a estabilidade de que necessita, a fim de transpor os primeiros e essenciais estágios de seu crescimento emocional”. Zanetti (2008) mostra, com base nos sociólogos alemães Adorno e Horkheimer, que, quando a criança descobre que o pai não personifica absolutamente a força, a justiça e a bondade e, sobretudo, que não concede a proteção que ela inicialmente espera dele, esta criança sente que não pode mais se identificar com ele por muito tempo, não pode interiorizar as exigências colocadas pela família, a qual, apesar de todos os seus aspectos repressivos, contribuía decididamente para a formação do indivíduo autônomo. Os jovens que são criados dessa forma tendem a se submeter a qualquer tipo de autoridade, não importa o seu conteúdo, contanto que ela ofereça proteção, satisfação narcisista, vantagens materiais e a possibilidade de despejar em outros o sadismo no qual se respaldam a desorientação inconsciente e o desespero.

Pais atenciosos e presentes são capazes de assumir um posicionamento seguro e confiante diante da criança para que ela cresça de modo saudável. Precisam dar a quantidade exata de amor e, ao mesmo tempo, manter um grau eficaz de autoridade, que não é um simples valor cultural característico da família tradicional. É preciso que saibam dar a quantidade exata de amor e, ao mesmo tempo, manter um grau eficaz de autoridade. De acordo com Leticia Solis-Ponton, citada por Zanetti (2008, p. 72), a parentalidade organiza o pensamento dos pais diante de seu filho, diante de si e o pensamento da criança, 'que aprende que pais e crianças têm atribuições diferentes, que filha e filho não são a mesma coisa que pai e mãe'. Isso garante que o saber dos pais seja assegurado [...] como o poder de colocar os interditos e fixar, de maneira cultural, as 'regras', que formam o núcleo da parentalidade e os alicerces da organização social. (grifo da autora). Segundo a filósofa 
Hannah Arendt (2001), no mundo de hoje os pais recusaram a autoridade e isso quer dizer que recusam a assumir a responsabilidade pelo mundo ao qual trouxeram as crianças (p. 240). Uma posição fragilizada dos pais, principalmente no que se refere à criança pequena, poderia propiciar a formação de uma personalidade frágil, com consequências sérias.

Mais sério do que tudo o que foi indicado, segundo Fleig (2000) é o fato de que já se pode perceber, presentes na sociedade, subjetividades marcadas pelo enfraquecimento da responsabilidade, desaparecimento do sentido comum dos limites, obscurecimento da faculdade de julgar e de estabelecer uma hierarquia de valores. Tudo o que se disse a respeito dos papéis parentais e dos sentimentos que se desenvolvem na criança em consequência da falta de autoridade paterna reflete-se rapidamente na escola, onde ela apresenta comportamentos de agressividade, teimosia e agitação, muitas vezes difíceis de serem controlados.

Como já ficou claro que um dos fatores mais importantes para levar as crianças e jovens a um comportamento inadequado é a forte influência dos diversos meios de comunicação, em especial, da internet, - particularmente publicidades incisivas e promoção de desafios perigosos muitos pais têm tentado monitorar o que seus filhos veem no YouTube. Entretanto, como uma mãe se expressou: "Parece que, quanto mais bloqueio, mais opções aparecem." Por isso, famílias e associações estão criando estratégias diversas para filtrar o que seus filhos acessam. Suas críticas se dirigem principalmente a vídeos de 'unboxing" (abertura de presentes ou embalagens, para fazer publicidade de produtos), consumo de guloseimas e desafios considerados perigosos. Um desses movimentos que tentam lutar contra essa influência maléfica dos vídeos, o Milc (Movimento Infância Livre de Consumismo), faz campanhas de mobilização contra o consumismo na internet e pretende reunir dicas de páginas virtuais adequadas. Uma das criadoras desse movimento, a publicitária Mariana Sá, raciocina, com bastante bom senso: "Boicotar a tecnologia é utópico", acrescentando que é preciso controlar. Entre as emissões que podem provocar consequências extremamente danosas para os jovens, estão os desafios aos jovens no sentido de mostrarem coragem para se automutilarem intencionalmente ou até se suicidarem. O suicídio dos jovens, seja provocado por desafios da internet, seja produto de desajustes pessoais e depressão é outra grande preocupação paterna. Depois que os pais de camada média foram alertados recentemente de que os suicídios estavam crescendo em número em colégios da elite paulistana, as escolas passaram a relatar casos ocorridos com seus alunos. Entre esses colégios podem ser citados o Bandeirantes (dois casos), o Agostiniano São José, o Vértice, entre outros. Especialistas consultados deram conselhos aos pais no sentido de ficarem atentos a mudanças no comportamento dos filhos, como isolamento, choro, tristeza, alterações no apetite e no sono. O presidente da Sociedade Brasileira de Inteligência Emocional, Rodrigo Fonseca, indica que "o ideal é um diálogo de igual para igual dos pais com os filhos para não afastar o jovem" e o papel da escola é observar atentamente para notificar os pais. Diante dos sinais mencionados, é indicada uma "força-tarefa" com apoio familiar e profissionais especializados, com ações focadas no diálogo e no carinho.

Adriana Rizzo, do Centro de Valorização da Vida (CVV), acrescenta que é necessário ter atenção para questões que podem ser típicas de determinadas faixas etárias, principalmente com adolescentes. Segundo ela, os jovens querem resolver tudo imediatamente, mas só depois de ficarem mais velhos é que conseguem entender que a vida tem seu próprio ritmo. Às vezes estão vivenciando uma decepção amorosa, em outros casos, repetiram o ano na escola. Esses jovens estão experimentando diversas coisas ao mesmo tempo e ainda não atingiram a maturidade suficiente para lidar com elas simultaneamente. 
As conclusões do estudo de Zanetti (2008), que não se limitou a analisar reflexões de psicólogos, educadores e filósofos, mas que fez estudo empírico com muita seriedade e profundidade, baseado em observações das crianças, seu comportamento tanto na família como na escola, assim como em entrevistas com os pais e professoras dessas crianças, são as seguintes:

- a parentalidade fica comprometida quando o casal não consegue construir uma relação de qualidade no laço conjugal;

- ainda que seja natural atualmente que a criança ocupe um lugar de privilégios e destaque na família de classe média, este lugar de privilégios e direitos será maior e isento de limites à medida que os pais não tenham capacidade de frustrar seus filhos;

- a coerência entre os pais e de cada um com seus princípios e fundamentos educativos é essencial para que não se comportem de maneira ambivalente, mas consistente e que possam transmitir confiança à criança $\mathrm{e}$

- o fato de não conseguirem incorporar os valores contemporâneos com critérios ou de maneira bem elaborada está relacionado com a capacidade do casal de elaboração frente ao 'novo' e que esta pode causar conflitos e afetar o surgimento de um posicionamento coerente diante dos filhos.

É preciso salientar que as transformações da sociedade contemporânea tendem a influenciar a vida familiar e a atuação paterna, mas, por si só, não constituem um fator que irá comprometer o desempenho dos papéis parentais. A fragilização desses papéis ocorre e poderá efetivamente prejudicar a qualidade da interação com a criança quando os pais não conseguem discernir e se posicionar com critérios diante da interferência dos valores contemporâneos, dos saberes especializados, do posicionamento de terceiros ou da influência dos meios de comunicação de massa e passam a assimilar esses novos conhecimentos e valores de forma indiscriminada, provocando conflito de valores numa dinâmica ambivalente. Isso ocorre quando os pais não se sentem seguros com a postura que assumem e, assim, não se posicionam com critérios para a assimilação dessa postura. Essas dificuldades, que são particulares a cada um e de ordem psíquica, podem atrapalhar ou até impedir um contato com as reais capacidades e possibilidades do filho, o que é condição sine qua non para que possam adequar os conhecimentos adquiridos, os fundamentos e princípios com a dinâmica específica de cada criança.

Para não incorrerem no erro de confundir "autoritarismo" com "autoridade" ou o ideal de dar "maior liberdade" para a criança com um "alto grau de permissividade", é necessário que os pais saibam acomodar ou assimilar "o novo" com coerência e critérios, ou seja, dependerá da capacidade de elaboração dos conflitos destes pais, inclusive enquanto casais. As dificuldades enfrentadas pelos pais são tão evidentes que a emissora de Tv SBT, que veicula o programa 'Super Nanny', já recebeu cerca de 20.000 inscrições e comunicações de famílias, em sua maioria de classe média, para continuar com essa programação, que estava em sua terceira temporada no ano em que Zanetti escreveu sua dissertação (2008). É muito provável que o apoio do companheiro, ainda que simbólico, e uma forte interação entre o casal dê mais suporte para as dificuldades psíquicas, quando essas dificuldades estão relacionadas com as condições de existência na contemporaneidade. Também isso traz maior possibilidade de assimilar os novos valores e de adequação no desenvolvimento dos papéis parentais. $\mathrm{O}$ fator mais influente e mais prejudicial na relação pais e filhos é o psicológico, a condição psicológica dos pais. Explicando melhor: quando os pais, pai e mãe, se deixam mais facilmente influenciar, o contexto sociocultural pode interferir de forma mais forte e prejudicial. Isso quer dizer que condições sociais, econômicas e culturais que interferem na família estimulam construções subjetivas mais solitárias e relacionamentos frágeis 
porque o medo da separação não contempla mais culturalmente modos de serem acolhidos e as pessoas preferem não se arriscar em relacionamentos profundos.

As camadas médias da população brasileira já incorporaram os valores educacionais contemporâneos e a criança nasce em um ambiente que lhe reserva o papel de 'protagonista', com mais conforto e liberdade para explorar e conhecer o mundo e o ambiente familiar. Os valores atuais, especialmente os de democracia e igualdade, possibilitaram à criança o franqueamento das fronteiras, rígidas no passado, entre categoriais sociais (homem/mulher; adulto/criança) e uma maior liberdade de expressão aos membros da família. A apropriação sensata dos valores de democracia possibilita aos pais proporcionar uma educação que não é rígida, que dá maior espaço para a participação da criança na família, promovendo formas de relações mais compreensivas e próximas da criança, ao mesmo tempo em que os pais levam em consideração que seus filhos ainda não são completamente capazes de ter uma opinião condizente sobre determinados assuntos e que, portanto, cabe a eles compreender que a criança em idade precoce precisa ser orientada e respeitada dentro de suas possibilidades e capacidades características.

\section{Considerações Finais}

Essas novas formas de relacionamento entre pais e filhos são, naturalmente, difíceis de serem compreendidas e assimiladas, não são isentas de conflitos pelos pais, requerendo uma maior capacidade de elaboração dos pais porque estamos numa etapa de transição. Os valores tradicionais que serviram de base para a educação de nossos pais são hoje questionados e os modelos novos ainda não estão estabelecidos. Assim, torna-se cada vez mais difícil poder dar uma contribuição significativa para a transformação da sociedade em que vivemos em um mundo mais humano e a tarefa parental encontra muitos obstáculos para poder ser desempenhada a contento preparar os filhos para essa missão.

Nesse contexto, torna-se necessário que os pais construam uma teoria de apoio consistente para suas práticas. O que isso quer dizer, construir uma teoria? Construir uma teoria significa refletir, de preferência antes que os filhos nasçam - mas se esses já nasceram, que os pais comecem imediatamente a refletir sobre a educação que acham melhor transmitir a seus filhos, que leiam obras de valor sobre o tema, que conversem com especialistas, psicólogos, educadores, sociólogos, outros pais que, pela observação, parecem ter tido sucesso na forma como atuaram em relação a seus filhos, enfim que aprofundem o assunto e procurem traduzir essas reflexões em suas práticas, com bom senso e coragem e, principalmente, agindo com base em consenso da parte do pai e da mãe, de modo que um não contradiga o outro para que a criança não perceba divergências entre o que o pai e a mãe dizem. Diz o filósofo e professor Mário Cortella que "o mundo que deixaremos para nossos filhos são os filhos que deixaremos para este mundo" 2 . Deixemos, pois, filhos para este mundo que tenham uma formação que lhes permita desenvolver a capacidade necessária para assumir os papéis de que hoje a sociedade está carente e a responsabilidade que deve acompanhar o conhecimento para que levem ao fim a tarefa que assumirem e não pensem simplesmente em possuir cada dia mais e desfrutar de tudo o que a sociedade pode oferecer, sem pensarem na retribuição daquilo que receberam tão generosamente.

Nossos filhos precisam, entretanto, saber que muitas das profissões que atualmente existem não existirão mais no futuro. Muitas são profissões de baixa remuneração, como empregados domésticos, frentistas de postos de gasolina, caixas de supermercado, motoboys, mas

\footnotetext{
${ }^{2}$ Palavras pronunciadas em entrevista na Rádio CBN.
} 
outras são de classe média, como corretores de imóveis, contadores, motoristas de táxi. Outras, ainda serão transformadas. Afinal, não serão mais necessários médicos, enfermeiros ou laboratoristas para tirar sangue, fazer ultrassom, diagnósticos simples ou cirurgias complexas. Também jornalistas não vão mais escrever matérias mastigando números, seja de estatísticas esportivas, seja de econômicas. A última vez em que isso ocorreu foi no início do século XX. O fato desorganizou tanto a estrutura do trabalho que do caos nasceram os movimentos fascistas e comunista. Poderá estar pintando agora algo semelhante.

\section{Referências bibliográficas}

ARENDT, Hannah. Entre o passado e o futuro. São Paulo: Perspectiva, 2001.

ARIÈS, Philippe. A história social da criança e da família. Rio de Janeiro: Zahar, 1975.

BAUMAN, Zygmunt. Quarenta e quatro cartas desde o mundo líquido. Madrid: Paidós, 2011.

CAFARDO, Renata. Suicídio de estudantes causa comoção nas redes sociais e reflexões em escolas. O Estado de São Paulo. Caderno Metrópole, p. A12, 24 abr. 2018.

DORIA, Pedro. Profissões acabarão. O Estado de São Paulo. Caderno Economia, p. B8, 16 de junho de 2017.

FREUD, Sigmund. Sobre o narcisismo: uma introdução. In: FREUD, S. A história do movimento psicanalítico, artigos sobre a metapsicologia e outros trabalhos. v. XIV. Rio de Janeiro: Imago, edição Standard Brasileira das Obras Psicológicas completas de S. Freud, (1914) 1969. p. 77-108.

HALMOS, Claude. L'Autorité expliquée aux parents. Paris: Le Livre de Poche, 2011.

HOUZEL, Didier. As implicações da parentalidade. In: SILVA, Maria Cecília Pereira da (Org.). Ser pai, ser mãe - parentalidade: um desafio para o terceiro milênio. São Paulo: Casa do Psicólogo, 2004. p. 47-51.

LAZARSFELD, Paul F.; MERTON, Robert K. Comunicação de massa, gosto popular e ação social organizada. In: COHN, Gabriel (Org.). Comunicação e indústria cultural. $4^{\mathrm{a}}$. ed. São Paulo: Companhia Editora Nacional, 1978. p. 230-253.

LEBRUN, Jean-Pierre. Um mundo sem limite: ensaio para uma clínica psicanalítica do social. Rio de Janeiro: Companhia de Freud, 2004.

MENGUE, Priscila. Filtro de vídeos na internet mobiliza pais. O Estado de São Paulo. Caderno Metrópole, p. A18, 6 maio 2018.

POSTMAN, Neil. Disappearance of childhood. Vintage Books, 1982.

POSTMAN, Neil. The end of education: redefining the value of school. Vintage Books, 1996.

SAID, Gustavo Fortes. Mídia, poder e história na era pós-moderna. Teresina: Edufpi, 1998.

WINNICOT, Donald Woods. Conversando com os pais. São Paulo: Martins Fontes, 1999.

ZANETTI, Sandra Aparecida Serra. Efeitos da fragilização dos papéis parentais em determinados comportamentos de crianças no ambiente escolar, na contemporaneidade. 2008. 198f. Dissertação (Mestrado em Psicologia Clínica) - Instituto de Psicologia, Universidade de São Paulo, São Paulo. 